Acta regionalia et environmentalica 1

Nitra, Slovaca Universitas Agriculturae Nitriae, 2013, p. 26-30

\title{
FINANCING OF UNIVERSITIES AND INNOVATIONS IN HIGHER EDUCATION FUNDING IN THE SLOVAK REPUBLIC
}

\author{
Monika REBEKOVÁ, Ol'ga ROHÁČIKOVÁ
}

Slovak University of Agriculture in Nitra, Slovak Republic

\begin{abstract}
The objective of the research on the theoretical, methodological, and scientific level will be the analysis of higher education financing in Slovakia and comparison of various financing strategies for higher education in the studied countries. Authors of the research paper analyze the Slovak model of financing of higher education institutions and the latest innovations in this model. Financing of universities, along with the quality of education are very discussed and actual issues.
\end{abstract}

Keywords: funding system, universities, inovations in financing, development of higher education, social support

The importance of higher education has recently been included into the context of building a knowledge society in Europe. Financing of universities, along with the quality of education are very discussed and actual issues. Financing of higher education is conceived to be of central importance for the future creation and enlargement of knowledge and research (Beblavý, 2011).

According to Dimitrova (2010), the process of globalization is interconnected with the higher education development. Globalization directly affects the whole higher education system - it raises its role but at the same time brings a number of challenges to it. Nowadays, many extensive higher education reforms have been implemented in Europe.

The system of financing of higher education in Slovakia has recently been enriched by a variety of significant changes and innovations. This paper contains a brief description of the simplicity of the current system of financing as well as analysis of the current situation in Slovakia based on the selected indicators.

\section{Material and methods}

There are many indicators we can use to compare different models of financing of higher education. One of the most important indicators is GDP, or public expenditure as a percentage of GDP. This indicator linked with other data, such as the number of students at universities or growth rate of GDP, can provide meaningful and important sources of information for us.

Using the comparative method, we performed an analysis of the received statistical data and then we accomplished confrontation of the statistical data based on selected indicators. The research sample consisted of students, and university graduates in an agreed time interval.

Our objective was to get the most exact results, so our research sample of students was divided to intern students, extern students, foreign students and PhD. students, with a time horizon consisting of two decades; the first decade: the years 1992-2001, the second decade: the years 2002-2011. For processing of the research results we use data analysis, mathematical and statistical techniques and methods of logical operations.

\section{Results and discussion}

Higher education financing in Slovakia

Space in which higher education exists and operates, is influenced by financing and legislation. Funding of higher education is - according to Act no. 131/2002 Coll. on universities - provided by the Ministry from the state budget through the following grants:

- grants for implementation of accredited study programs,

- grants for research, development or artistic activities,

- development grants for universities,

- social support for students.

The law determines the criteria for each grant. There are many differences between them. But essentially, there are two types of them: universities are evaluated according to the performance of the research and according to the performance in education. Very important criteria for defining the performance of universities in research are the following: number and types of publications, amount of funds collected to address research projects from domestic or foreign sources, number of students of doctoral programs, and research capacity. On the other hand, in the case we want to determine the performance in education, the amount of students and graduates in all study programs receives the highest priority.

As we can see in the figures, during the first decade, in the years 1992-2001, there was a massive, more than one hundred percent progress in the number of university students. A similar situation was also typical for the full-time students, their number increased by 90 percent in that period. Compared with the second decade, since 2002 the number of university students increased by $50 \%$, while the progress in number of full-time students accounted for just under $30 \%$.

On the other hand a rapid increase in the number of external students up to $400 \%$ that was typical for the first 


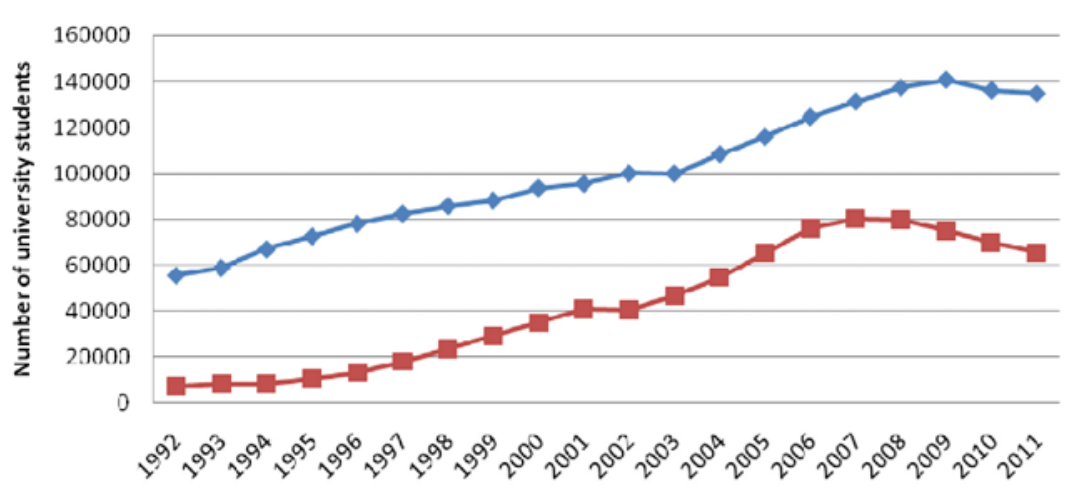

$\multimap$ Intern students

-Extern students

Figure 1 Number of university students in the years 1992-2011 (full-time students and external students)

Source: www.minedu.sk/vyrocne-spravy-o-stave-vysokeho-skolstva

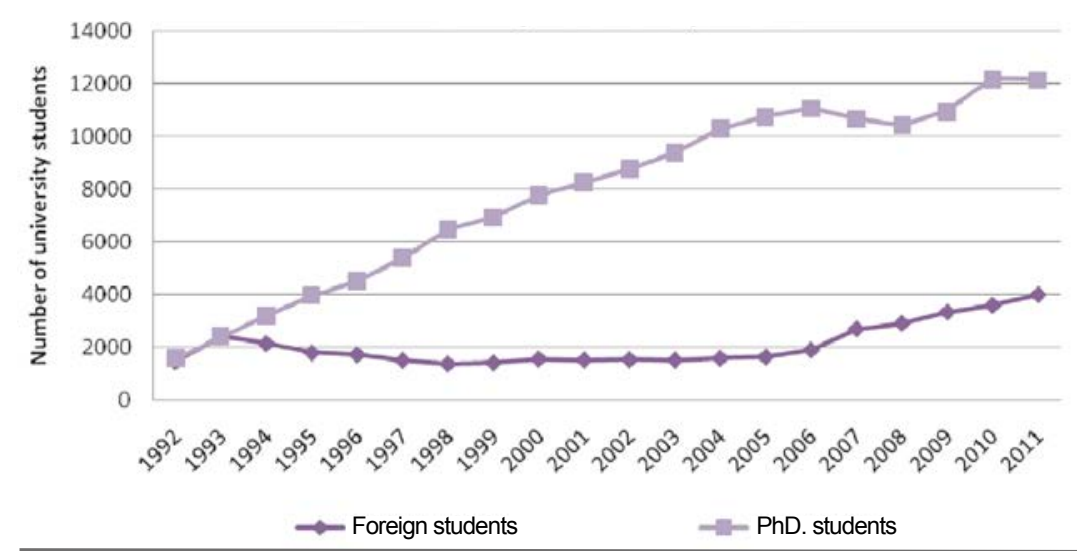

Figure 2 Number of university students in the years 1992-2011 (foreign students and PhD. students)

Source: www.minedu.sk/vyrocne-spravy-o-stave-vysokeho-skolstva

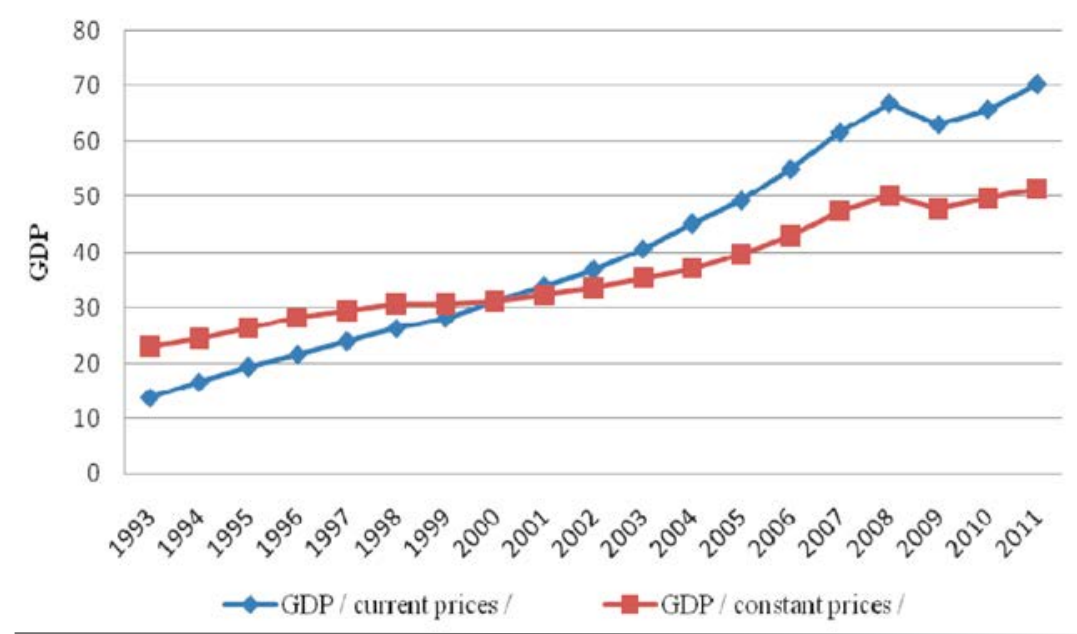

Figure 3 GDP in the years 1992-2011

Source: http://www.finance.sk/hospodarstvo/hdp/bezne-a-stale-ceny/ decade (figure 1), was changed in the second decade, during which the numbers of external students increased only by $60 \%$. Figure 2 shows significant changes in the number of foreign students particularly in the second decade, because during the years 1992-2001, this value was almost constant. In the second decade, we observe the increase in number of foreign students by more than $150 \%$, the first significant increase in the number of foreign students we can see in 2007. On the other hand, the amount of PhD. students increased up to $500 \%$ during the first decade, while in the next ten years their number has increased only by $35 \%$.

According to Mederly (2012), the financing of higher education in Slovakia in comparison with other countries is considerably insufficient. We do not speak only about absolute numbers, but a similar situation also applies to the level of GDP in these countries. The GDP and GDP growth for the period 1992-2011 is showed in the following figures. The data is represented in current and in constant prices in billions of $€$ (Figure 3.) For more details about representation of rapid percentage reduction of GDP growth, which took place in 2009, we can see the percentage of the GDP growth rate in Figure 4.

As the prognosis (Figure 4) of the Ministry of Finance for 2013 shows, there is a anticipation of increase by $2.1 \%$ of GDP. The anticipation of GDP growth estimated by the European Commission is $2.0 \%$. The estimation of the Ministry of Finance for the year 2014 is 3.5\%, the European Commission estimates $3.0 \%$.

But according to the latest forecast, the Slovak Ministry of Finance estimates that the economic growth for 2013 will be only $1.2 \%$. The finance department foresees the GDP increased by $2.9 \%$ in 2014, and by 3.3 $\%$ in 2015. The estimations for 2016 are therefore a little more optimistic, the Ministry of Finance forecasts growth of GDP up to $3.6 \%$.

The percentage of students enrolled in higher education and percentage of public expenditures on higher education in total public expenditures are compared in the Figure 5. The situation depicted in 


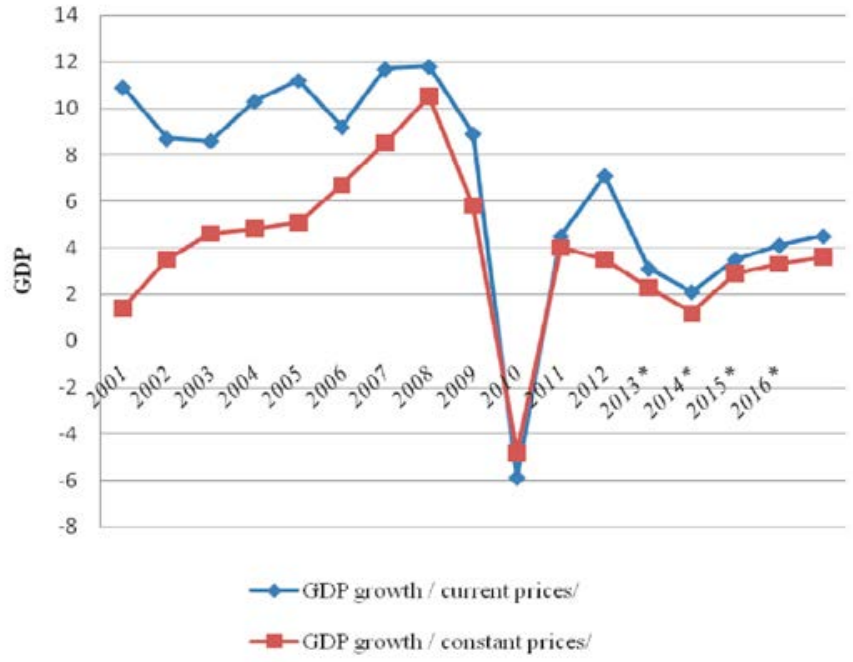

Figure 4 GDP growth rate and prognosis in \%, statistical data Source: http://www.sevis.sk/wp-content/uploads/Prognoza-SR-a-EU

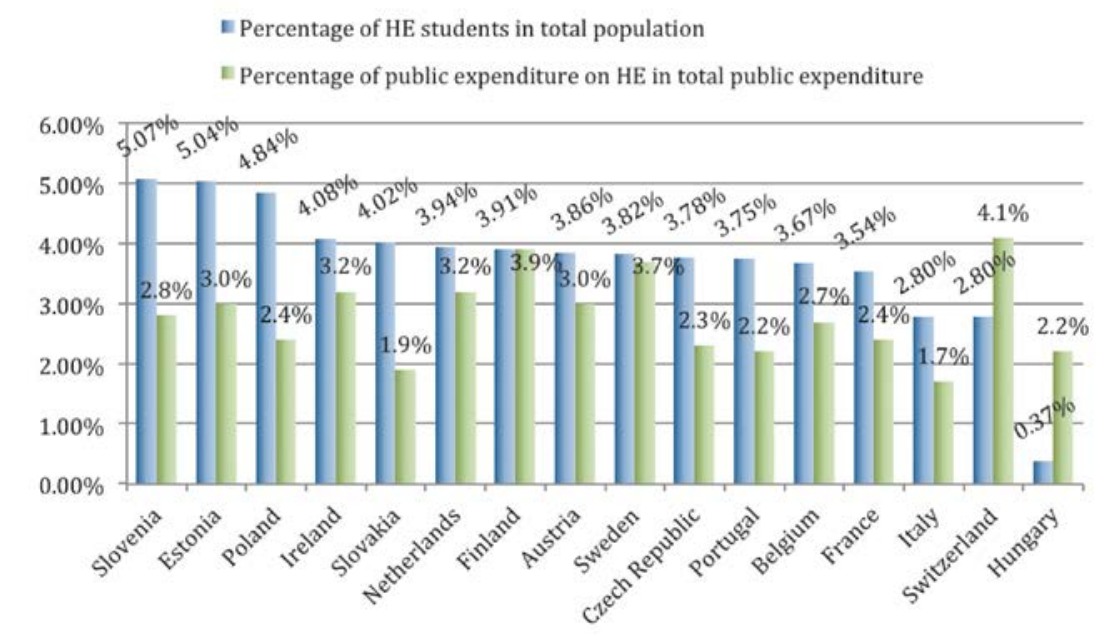

Figure 5 The percentage of students in total population, compared to public expenditure on higher education as percentage of total public expenditure Source: Eurostudent/ Eurostat, 2009: The Bologna in Higher Education in Europe: Key Indicators on the social dimension and mobility

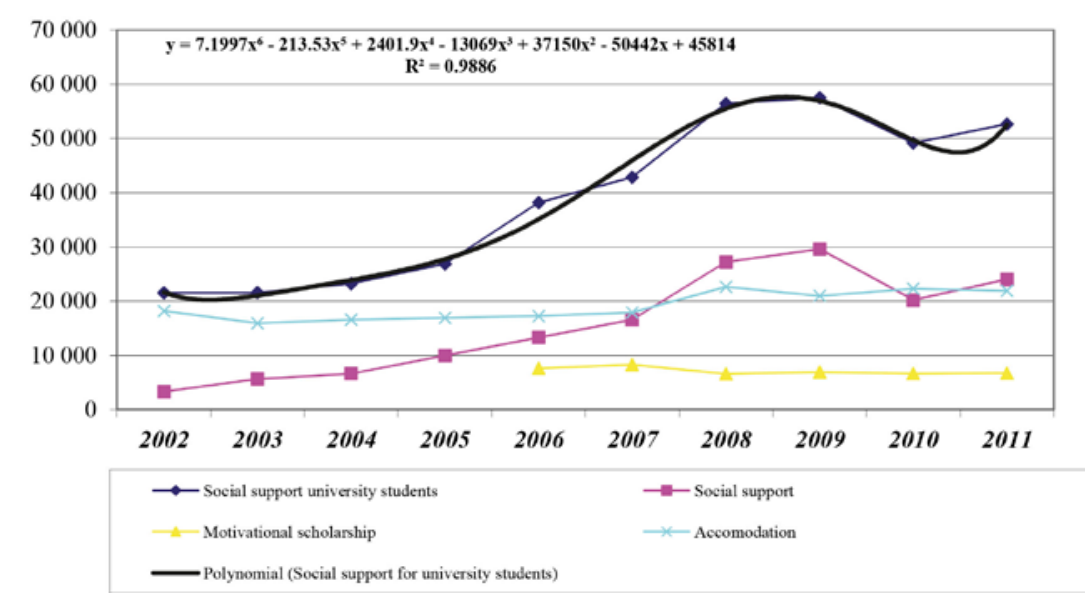

Figure 6 Structure of sub-element 07715 - Social support for university students Source: http://www.minedu.sk/rozpis-dotacii-zo-statneho-rozpoctu-verejnymvysokymskolam the Figure 5 seems to be unsatisfying for most countries, but fairly positive for Hungary and Switzerland. Nevertheless, the enrolment rate in those two countries was rising steadily between 2000 and 2009. This circumstance taken into account has led to the fact, that during this period, Hungary and Switzerland have been the only OECD countries where annual expenditure per student has actually been declining, a development that also gives reason for concern. We are aware that this kind of comparison is difficult because of different public funds allocation systems and the budget data do not take into account the relative GDP size differences, but the relationship between these two indicators can still be seen as an indicator of the importance that students and higher education are given in the country.

Nevertheless, not only this indicators influence higher education financing, but they can give a starting point for a discussion about diversity of financing systems.

\section{Innovations in higher education funding}

The methodology for allocating subsidies from the state budget to public universities is based on the provisions according to the Act no. 131/2002 Coll. on universities.

As we have mentioned above, grants for universities are calculated in the budget of the Ministry for 2012 using Programme 077 - Higher education and science, social support for university students. The program 077 - Higher education and science, social support for university students, consists of several sub-elements, and for more details, we bring more simple representation of the structure in the Table 1.

Point is that it is a very problematic theme, so we pay attention to at least some of the successful innovations. The subsidies for social support students in incentive grants for scholarships begin to take into account external students, and there is also a change in the provision of scholarships to $\mathrm{PhD}$. students, and resources for doctoral scholarships from sub-element 077 11 - Provision of higher education and the operation of university-shifted to 
Table 1 Structure of the 077 - Higher education and science, social support for university students

\begin{tabular}{|c|c|}
\hline Code of program & Name of program / sub-element \\
\hline \multicolumn{2}{|r|}{ Sub-elements } \\
\hline 077 & - higher education and science, social support university students \\
\hline 07711 & - provision of higher education and the operation of universities \\
\hline 07712 & - collegiate Science and Technology \\
\hline 07713 & - development of Higher Education \\
\hline 07715 & - social support university students, social and motivational scholarships \\
\hline
\end{tabular}

Source: http://www.minedu.sk/rozpis-dotacii-zo-statneho-rozpoctu-verejnymvysokymskolam

Table 2 The approved budget for public high schools in the years 2002-2011

\begin{tabular}{|l|c|c|c|c|c|c|c|c|c|c|c|}
\hline $\begin{array}{l}\text { Code of } \\
\text { program }\end{array}$ & $\mathbf{2 0 0 2}$ & $\mathbf{2 0 0 3}$ & $\mathbf{2 0 0 4}$ & $\mathbf{2 0 0 5}$ & $\mathbf{2 0 0 6}$ & $\mathbf{2 0 0 7}$ & $\mathbf{2 0 0 8}$ & $\mathbf{2 0 0 9}$ & $\mathbf{2 0 1 0}$ & $\mathbf{2 0 1 1}$ \\
\hline $\begin{array}{l}\text { Sub- } \\
\text { elements }\end{array}$ & \multicolumn{7}{|c|}{$\times 1.000 €$} \\
\hline 077 & $211,902.00$ & $241,292.00$ & $280,115.00$ & $308,704.00$ & $344,055.00$ & $360,139.00$ & $390,472.00$ & $423,556.00$ & $442,367.98$ & $424,982.10$ \\
\hline 07711 & $168,230.00$ & $196,193.00$ & $224,386.00$ & $241,440.00$ & $265,385.00$ & $270,679.00$ & $293,370.00$ & $314,846.00$ & $353,498.61$ & $261,445.23$ \\
\hline 07712 & $16,532.00$ & $17,879.00$ & $28,178.00$ & $32,080.00$ & $32,199.00$ & $33,727.00$ & $36,144.00$ & $39,600.00$ & $39,224.43$ & $106,048.24$ \\
\hline 0771201 & $11,089.00$ & $12,403.00$ & $18,385.00$ & $19,133.00$ & $19,584.00$ & $20,449.00$ & $23,529.00$ & $25,658.00$ & $26,218.08$ & $94,253.58$ \\
\hline 0771202 & $2,987.00$ & $2,987.00$ & $6,639.00$ & $7,967.00$ & $7,303.00$ & $7,303.00$ & $7,303.00$ & $8,630.00$ & $10,291.13$ & $9,302.66$ \\
\hline 0771203 & $1,327.00$ & $1,327.00$ & $1,494.00$ & $2,324.00$ & $2,324.00$ & $2,987.00$ & $2,324.00$ & $3,320.00$ & 0.00 & 0.00 \\
\hline 0771204 & 664.00 & 664.00 & 830.00 & 996.00 & 996.00 & 996.00 & 996.00 & 0.00 & 155.85 & 0.00 \\
\hline 0771205 & $465, .00$ & 498.00 & 830.00 & $1,660.00$ & $1,992.00$ & $1,992.00$ & $1,992.00$ & $1,992.00$ & $2,559.64$ & 2.492 .00 \\
\hline 07713 & $5,606.00$ & $5,643.00$ & $4,315.00$ & $8,299.00$ & $8,299.00$ & $12,912.00$ & $4,523.00$ & $11,617.00$ & 481.609 & 4843.58 \\
\hline 07715 & $21,533.00$ & $21,576.00$ & $23,236.00$ & $26,887.00$ & $38,174.00$ & $42,821.00$ & $56,437.00$ & $57,493.00$ & $49,163.33$ & $52,645.05$ \\
\hline 0771501 & $3,319.00$ & $5,643.00$ & $6,639.00$ & $9,958.00$ & $13,278.00$ & $16,597.00$ & $27,219.00$ & $29,594.55$ & $20,230.19$ & $24,000.00$ \\
\hline 0771502 & 0.00 & 0.00 & 0.00 & 0.00 & $7,635.00$ & $8,299.00$ & $6,580.00$ & $6,919.45$ & $6,648.40$ & $6,723.75$ \\
\hline 0771503 & $18,214.00$ & $15,933.00$ & $16,597.00$ & $16,929.00$ & $17,261.00$ & $17,925.00$ & $22,638.00$ & $20,979.00$ & $22,284.48$ & $21,921.30$ \\
\hline
\end{tabular}

Source: http://www.minedu.sk/rozpis-dotacii-zo-statneho-rozpoctu-verejnymvysokymskolam

Currency exchange rate: $1 €=30.1260$ SKK

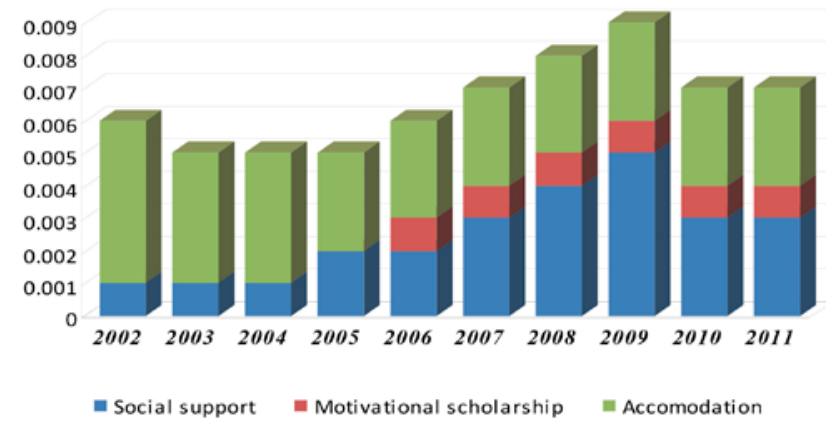

Figure $7 \quad 07715$-Social support students to GDP

Source: http://www.finance.gov.sk/Default.aspx?Ca$\mathrm{t} \mid \mathrm{D}=8822$, www.finance.gov.sk/ifp

element 0771201 - Operation and development of the infrastructure for research and development.

Based on the processed statistical data in the table 2, we see that even in 2003, the volume of paid social grants was 5.6 million $€$. But this is not comparable with the fact that in 2011, volume of paid social student scholarships reached 24 mil. $€$.

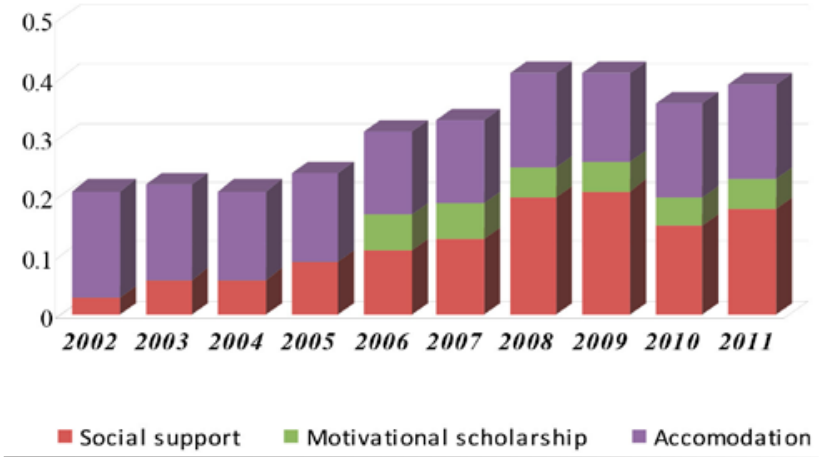

Figure 8 Social support for students ( $€ /$ student) Source: http://www.finance.gov.sk/Default.aspx?CatID=8822, www.finance.gov.sk/ifp

To analyze data on the structure of sub-elements 077 15 - Social support university students, we used the figure 6 with polynomial trend line, because of the fluctuating data. The degree of the polynomial was determined using extreme and minimum (maximum) values on the curve. In 
our case, there is a polynomial trendline grade 2 , because there is only one maxima (year 2009).

Self-evidently, the trendline is most reliable when its $R^{2}$ equal to 1 or close to 1 . It is necessary to note, that the $R^{2}$ value is 0.9886 , indicating a nearly perfect transfer line data.

Dependence of social support provided the university students as a percentage in relation to GDP in each year can be traced through the figure no 7 . The figure shows that the following percentage was increasing in the years 2004-2009, and during the next two years, it significantly decreased.

It is very important to examine the results projected in the figure 8 , where we investigate the amount of social support for university students in full-time study, expressed in $€$ per student, depending on individual years. The figure shows that the amount of social support provided to one student after years of stagnation (2002-2004) had an upward trend since 2005 until 2009. Then, we observe a reduction of the value in 2010 with a very slight increase in 2011.

\section{Conclusion}

The system of financing higher education in Slovakia is mostly based on the outcomes of universities. However, it the major factor influencing universities is not the volume of funds, but mostly a system according to which they are redistributed (Barta, 2011). The funds granted by the EU Structural Funds are for the colleges aids, but certainly they are not the solution to this problem. The higher level of investments in universities and funds for basic research will result in increased quality; diversity will be reached by providing universities with conditions for more powerful regionally-focused roles; stimulating and enabling innovation will result in changing universities as more effective partners with private sector. (Dimitrova, 2010)

As reported by Pišút (2011), the processes to improve education and research in Slovakia are not easy and it will be necessary to focus on it more effectively in several areas, especially on the improved funding of universities. However, this will require the full cooperation of the Ministry and municipal authorities with universities (Mederly, 2011).

From next year, assessment of Higher Education will be realized already through stricter criteria, motivation for us is that the new conditions of assessment of education should bring better educational programs, which will be connected with their financing.

Colleges will now be evaluated primarily according to the research areas in which they operate and carry out higher education. For the first time, therefore, we meet with the evaluation based on three aspects: conditions of research, outcomes of research and approval of research results. However, the question for us is, whether the upcoming innovations and new efforts going this direction will be a real asset for the development and prosperity of Higher Education.

\section{References}

BEBLAVÝ, M. - KIŠŠ, Š. 2010. 12 riešení pre kvalitnejšie vysoké školy. [s. I.] :SGl, 2010. Dostupné online. ISBN 978-80-89244-52-2. BURKE, J. C. 2002. Funding Public Colleges and Universities for Performance, The Rockefeller Institute Press, Albany, New York, 2002

Compendium on financing of higher education, Final report of Financing the Students' Future project, January 2013

Eurostudent/Eurostat. 2009. The Bologna Process in Higher Education in Europe: Key Indicators on the social dimension and mobility.

EUBAUEROVÁ, E. a i. Reforma systému financovania vysokých škôl v SR. [s. 1.] : [s. n.].

Funding higher education in the Slovak Republic: basic principles, Bratislava : Ústav informácií a prognóz školstva, mládeže a telovýchovy. ISBN 8070980559

GOLIAŠ, P. Fakty o financovaní školstva [online]. INEKO, 26.1.2011, rev. 2011-02-09. [cit. 2012-12-23]. Dostupné online.

DIMITROVA, V. 2010. Higher Education in the Globalized World - Key Elements and Perspectives, Proceedings of the World University Congress, v. I, Canakkale, 2010, p. 398-409

MEDERLY, P. 2006. Systém financovania vysokého školstva na Slovensku a jeho vplyv na vysokoškolský systém. Národná štúdia vypracovaná v rámci OECD - IMHE projektu Systémy financovania a ich vplyv na vysokoškolské systémy, Bratislava, 2006. Anglická verzia národnej štúdie je dostupná na http:// www.oecd.org/dataoecd/20/61/38308094.pdf

MEDERLY, P. 2009. Systém financovania verejných vysokých škôl a jeho zmeny od roku 2006. Bratislava : [s.n.]. 2009

OECD. Education at the Glance. [s. I.]: OECD. 2010. Dostupné online. ISBN 978-92-64-07566-5.

VLÁDA SR. Návrh koncepcie dalšieho rozvoja vysokého školstva na Slovensku pre 21. storočie [online]. 6.8.2000, [cit. 2012-1223]. Dostupné online.

http://ec.europa.eu/economy_finance/publications/european_economy/2012/pdf/ee-2012 7_en.pdf

Metodika rozpisu dotácií zo štátneho rozpočtu verejným vysokým školám na rok 2008-2012

http://www.arra.sk/sites/arra.sk/files/peter_mederly_2009_ system_financovania_vvs_a_je ho_zmeny_od_roku_2006.pdf

\section{Contact address:}

Ing. Monika Rebeková, Slovak University of Agriculture in Nitra, Department of Public Administration, e-mail: xrebekova@is.uniag.sk; doc. Ing. Ol'ga Roháčiková, PhD., Slovak University of Agriculture in Nitra, Department of Public Administration, e-mail: olga.rohacikova@uniag.sk 